\title{
Phytosociological study of coastal flora of Devbhoomi Dwarka district and its islands in the Gulf of Kachchh, Gujarat
}

\author{
L. Das $^{*}$, H. Salvi ${ }^{2}$, R. D. Kamboj ${ }^{3}$ \\ ${ }^{1,3}$ Gujarat Ecological Education and Research Foundation, Gandhinagar, Gujarat, India \\ ${ }^{2}$ Department of Botany, Songadh Government Science College, Tapi, Gujarat, India \\ *Corresponding Author: lopa.das1@gmail.com; Tel.: +91-7573020436
}

Available online at: www.isroset.org

Received: 16/May/2019, Accepted: 02/Jun/2019, Online: 30/Jun/2019

\begin{abstract}
The study described the diversity and phytosociological attributes of plant species (trees, shrubs and herbs) in coastal areas of Devbhoomi Dwarka District and its islands in the Gulf of Kachch. A random sampling method was employed in this study. A total of 243 plant species were recorded of which trees and shrubs represented with 30 specieseach. Grasses \& sedges were also represented by 30 species and 29 species were climbers. Among the tree and shrub species, Prosopis juliflora showed the highest density (373.51 ind. /ha), frequency (63.50.67\%), relative density (30.19.7\%), relative frequency (24.41\%) and relative abundance (7.68\%).Regarding herb species, Aristida redacta represented the highest density (3.97ind./sq.m) and frequency (39.02\%). Moreover, the highest importance value index was measured in Prosopis juliflora (62.28) among trees \& shrubs and Aristida redacta (31.51) among herbs. The Abundance/Frequency ratio of trees, shrubs and herb species showed contagious distribution pattern within the study area. The present study also includes $\alpha$ diversity (Shannon diversity index, Simpson's Index, species richness, evenness index) of the coastal terrestrial plants.
\end{abstract}

Keywords: Phytosociological, Abundance/Frequency, $\alpha$ diversity, Devbhoomi Dwarka, Gulf of Kachchh.

\section{Introduction}

Coastal landscapes and their typical ecosystems are highly dynamic and fragile which are characterized by steep environmental gradients and controlled by geomorphological, physical and biological processes. Despite several constraints, coastal areas are highly diversified offering a wide range of floral diversity. Apparently, the coastal flora is more influenced by the geological setting and climate of the region. Specificity of the flora along the coastline is attributed to the presence of sand dunes, rocky coasts, mud flats, marshlands and intertidal and tidal zone areas. In addition, coastal areas form a unique ecosystem owing to combined influence of both fresh and saline water. This interaction causes the coastal landforms to support large diversity of flora and fauna which are crucial to the ecosystem. Coastal vegetation provides habitats, food and fodder for fauna as well as protection from the wave action. Coastal sand is continually being eroded and deposited on the shore by wave action. Therefore, the role of vegetation in dune fixation is critical since, they serve as wind trappers, sand binders and dune stabilizers $[1,2]$. Apart from natural events, coastal areas are subjected to constant anthropogenic pressure which disturbs the coastal ecosystem. Therefore, it is a subject of prime importance to study the coastal areas in their natural state.

\section{Related Work}

With variant geological setting, the coastline of Devbhoomi Dwarka District and its islands in the Gulf of Kachchh (GoK) harbour different types of vegetation which include mangrove and their associates, scrub jungles, grassland, aquatic, and sand dune vegetation. In past, different aspects of Coastal flora have been studied by many researchers $[3,4,5,6,7,8,9,10,11,12$, $13,14,15,16$ and 17].

Though several reports on coastal flora are available but the entire floristic composition and quantification has not been alone. The species diversity may change with time and locations due to many existing factors. Therefore seasonal assessment is essential. The present study aims to generate such information of coastal terrestrial flora of Devbhoomi Dwarka District and its islands in GoK. 


\section{Study area}

\section{METHODOLOGY}

Devbhoomi Dwarka district of India is located on the southern coast of the GoK, in Gujarat state. It extends between $21.42^{\circ}$ to $22.58^{\circ} \mathrm{N}$ Latitude and $68.58^{\circ}$ to $70.40^{\circ}$ E Longitude [18]. Coastal areas of the district are distributed in three Talukas which are Okhamandal, Kalyanpur and Khambhaliya. Nine Islands viz., Ajad, Beyt Dwarka, Bhaidar, Dabdaba, Dhani, Gadu, Leffa, Kalubhar and Panero have been covered in this district. The soil of Devbhoomi Dwarka district is calcareous and alkaline in nature with grain size varying from silty loam to clay [19]. The district receives average rainfall of $596 \mathrm{~mm}$ [20].

\section{Field Data collection}

The present work is based on the survey of vegetation occurring in coastal areas and its 9 islands of Devbhoomi Dwarka district during 2011-2015. The area was surveyed on foot and random sampling method was followed. In the coastal area,line transects of $500 \mathrm{~m}$ were laid perpendicular to HTL (High Tide Line to landward side) by using $5 \mathrm{~km} \times 5 \mathrm{~km}$ grid laid over land use/land cover maps. Distance of $5 \mathrm{~km}$ between two subsequent line intersects was maintained using Global Positioning System (GPS).Within each transect, quadrates were laid at an interval of $20 \mathrm{~m}, 5 \mathrm{~m} \times 5 \mathrm{~m}$ for trees and shrubs and $1 \mathrm{~m} \times 1 \mathrm{~m}$ for herbs, grasses and climbers [21, 22, 23]. However, to enrich the species inventory the opportunistic coastal area at each site (areas falling out side of the quadrates) were also explored and monsoon data for herbaceous plants were also recorded in the same sampling plots. The coastal areas of Devbhoomi Dwarka District and its Islands were explored by laying a total of 46 transacts comprising of 915 quadrates $(1 \mathrm{~m} \times 1 \mathrm{~m}$ size) and 589 quadrates $(5 \mathrm{~m} \times 5 \mathrm{~m}$ size $)$, respectively. Within

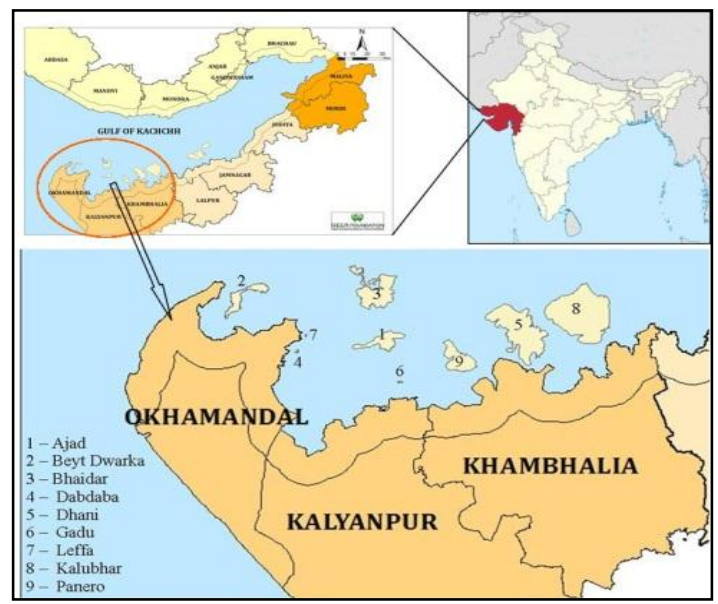

Figure 1. Study area (Coastal areas and 9 islands of Devbhoomi Dwarka district) each sampling plot the number and name of all the trees, shrubs and herbs were counted and recorded. The plants were collected in the flowering and fruiting stages and were identified by using different available floristic keys [24, 25, 26, 27, 28]. Documentation was done in the form of photographs as well as plant specimen were preserved by preparing herbarium and deposited in the GEER Foundation, Gandhinagar, Gujarat for future reference.

\section{Data Analysis:}

Phytosociological characters like Density (D), relative density (RD), frequency (F), relative frequency (RF), abundance (A), relative abundance (RA) and Importance Value Index (IVI) were calculated by using different formulas [29] and abundance frequency ratio $(\mathrm{A} / \mathrm{F})$ for Tree, shrub and herb species were also calculated through distribution patterns of Whitford [30]. Plant biodiversity was calculated by using different standard equations such as Shannon- Wiener diversity index [31], Simpson's index [32], Evenness index [33] and Species richness index [34].

\section{RESULTS AND DISCUSSION}

\section{Qualitative analysis}

The coastal areas and 9 islands of Devbhoomi Dwarka district were found predominantly covered with shrubby and herbaceous species including grasses. A total 242 Angiosperm and 1 Gymnosperm species belonging to 177 Genera and 61 Families were recorded (Table 1, Annexure 1). Angiosperm plant diversity includes 202 Dicot and 40 Monocot species. The ratio of Monocots to Dicots was 1:9.0 Families, 1: 5 Genera and 1:5.1 Species. The ratio of Family to Genera and Species was 1: 2.9: 4.
Table 1. Floral richness in Coastal areas of Devbhoomi Dwarka District

\begin{tabular}{|c|c|c|c|}
\hline & Family & Genera & Species \\
\hline A. Angiosperm & & & \\
\hline Dicotyledons & 54 & 144 & 202 \\
\hline Monocotyledons & 6 & 32 & 40 \\
\hline B. Gymnosperm & 1 & 1 & 1 \\
\hline Total & $\mathbf{6 1}$ & $\mathbf{1 7 7}$ & $\mathbf{2 4 3}$ \\
\hline
\end{tabular}


Among 202 dicot species sub-class Polypetalae exhibited the highest no of species (97 species), followed by Gamopetalae (74 species) and Monochlamydeae (31 species). Within Polypetalae, Calyciflorae group was represented with the maximum number of species (52), followed by Thalamiflorae and Disciflorae. Ratio of subclasses, Polypetalae to Gamopetalae to Monochlamydae was 1:0.8:0.3 and in the subclass Polypetalae, ratio of groups Thalamiflorae to Disciflorae to Calyciflorae was 1:0.45:1.58 (Figure 2).

During study, it was revealed that Poaceae was the largest family in Monocotyledons represented by 23 species and 20 Genera, whereas Fabaceae was the largest family among Dicotyledons represented by 20 species and 12 Genera. Out of 61 families, only 11 families were represented with more than half of the species recorded and 22 families were represented with single species. The genera Ipomoea had the highest number of species i.e. 8 followed by Cassia and Euphorbia genera both represented with 6 species. Among recorded 177 genera, 28 genera were represented by two species and 137 genera were represented with a single species (Annexure 1).

Habit wise distribution of angiosperms is illustrated in Figure 2. Among 243 recorded species, herbs were represented by the highest number of species (124), followed by trees, shrubs and grasses \& sedges represented with 30 species each and climber (29 species).

Among 3 talukas, the highest species diversity was found in Khambaliya taluka (207 species) followed by Okhamandal (192 species) and Kalyanpur (169 species). Among islands, Beyt Dwarka showed the maximum species diversity (166 species) followed by Azad (120 species) and Gadu (118 species). The lowest species diversity was found in Kalubhar island with 24 species (Figure 4). High floral diversity in Beyt Dwarka may be due to its proximity to coast and human interference due to tourist influx as well as fishermen. It was observed that, the islands near to the coast have high floral diversity, which is similar to the adjoining coastal area. Human beings, winds and water current help to disperse the seeds of various species in such islands and after that great struggle for survival of the plant species acclimate to island conditions ensues. Other islands were with less floral diversity and one of the reasons may be isolation and distance from coastal area. It was reported that a total of 127 vascular plants and a species of Gymnosperm recorded from Beyt Dwarka Island [16]. In that study, the dicotyledonous plant included 45 families, 91 genera and 113 species, and the monocotyledonous plant included 3 families, 11 genera and 13 species [16].

\section{Quantitative analysis of trees and Shrubs:}

During the quadrate sampling, a total of 17 species of trees and shrub were recorded. Among the 17 species, Prosopis julifloraex habited the highest density (373.51 ind./ha), followed by Capparis decidua (135.82 ind./ha), Zizyphus nummularia (112.73 ind./ha) and Salvadora persica (112.73 ind./ha). On the other hand, the lowest density (3.40 ind/ha) was observed in Acacia senegal. The highest frequency (63.50\%) was measured in Prosopis juliflora followed by Zizyphus nummularia $(32.94 \%)$ and Capparis decidua (26.99\%). The lowest frequency was recorded in Acacia senegal (0.85\%). (Table 2) 
Distribution of species is one of the important aspects of ecological studies, which has previously attracted attention of a number of ecologists [30, 35, 36, 37]. A value of abundance and frequency ratio below 0.025 was considered as regular distribution, between 0.025 to 0.050 as random and more than 0.050 as contagious distribution pattern [38]. In the present study, A/F values for different tree and shrub species revealed that all the species had contagious distribution pattern in the district (Table 2). It has been stated that the $\mathrm{A} / \mathrm{F}$ ratio as a measure of contagiousness among plant population was widely accepted [30].

Important Value Index determines the extent of dominance of a species in the structure of a forest stand [39]. It is said that species with the greatest importance value are the leading dominant of the particular vegetation. Accordingly the leading dominant tree and shrub species of coastal areas of Devbhoomi Dwarka district was Prosopis juliflora (62.28) followed by Capparis deciduas (27.93) and Zizyphus nummularia (26.24). On the other hand, the least dominant species was Acacia Senegal (5.82) (Table 2).

Table 2. Phytosociological attributes of tree and shrub species in coastal areas and its islands of Devbhoomi Dwarka district in

\begin{tabular}{|c|c|c|c|c|c|c|c|c|c|}
\hline \multicolumn{10}{|c|}{ GoK } \\
\hline No. & Botanical name & D (ind./ha) & $\mathbf{F}(\%)$ & $\mathbf{A}$ & $\mathbf{A} / \mathbf{F}$ & RD (\%) & RF (\%) & RA (\%) & IVI \\
\hline 1 & Prosopis juliflora & 373.51 & 63.50 & 588.24 & 9.26 & 30.19 & 24.41 & 7.68 & 62.28 \\
\hline 2 & Capparis decidua & 135.82 & 26.99 & 503.14 & 18.64 & 10.98 & 10.38 & 6.57 & 27.93 \\
\hline 3 & Zizyphus nummularia & 112.73 & 32.94 & 342.27 & 10.39 & 9.11 & 12.66 & 4.47 & 26.24 \\
\hline 4 & Salvadora persica & 112.73 & 16.13 & 698.95 & 43.33 & 9.11 & 6.20 & 9.13 & 24.44 \\
\hline 5 & Euphorbia nivulia & 83.53 & 26.32 & 317.42 & 12.06 & 6.75 & 10.12 & 4.15 & 21.01 \\
\hline 6 & Acacia nilotica & 83.53 & 18.85 & 443.24 & 23.52 & 6.75 & 7.25 & 5.79 & 19.79 \\
\hline 7 & Grewia tanex & 80.14 & 18.68 & 429.09 & 22.98 & 6.48 & 7.18 & 5.60 & 19.26 \\
\hline 8 & Grewia villosa & 76.06 & 16.81 & 452.53 & 26.92 & 6.15 & 6.46 & 5.91 & 18.52 \\
\hline 9 & Commiphora wightii & 59.08 & 13.58 & 435.00 & 32.03 & 4.77 & 5.22 & 5.68 & 15.68 \\
\hline 10 & Cassia auriculata & 58.40 & 12.56 & 464.86 & 37.00 & 4.72 & 4.83 & 6.07 & 15.62 \\
\hline 11 & Calotropis procera & 19.02 & 3.90 & 486.96 & 124.70 & 1.54 & 1.50 & 6.36 & 9.40 \\
\hline 12 & Salvadora oleoides & 17.66 & 3.57 & 495.24 & 138.90 & 1.43 & 1.37 & 6.47 & 9.27 \\
\hline 13 & prosopis cineraria & 8.15 & 2.04 & 400.00 & 196.33 & 0.66 & 0.78 & 5.22 & 6.67 \\
\hline 14 & Cadaba fruiticosa & 5.43 & 1.36 & 400.00 & 294.50 & 0.44 & 0.52 & 5.22 & 6.19 \\
\hline 15 & Ephedra foliata & 4.07 & 1.02 & 400.00 & 392.67 & 0.33 & 0.39 & 5.22 & 5.94 \\
\hline 16 & Mimosa hamata & 4.07 & 1.02 & 400.00 & 392.67 & 0.33 & 0.39 & 5.22 & 5.94 \\
\hline 17 & Acacia senegal & 3.40 & 0.85 & 400.00 & 471.20 & 0.27 & 0.33 & 5.22 & 5.82 \\
\hline \multicolumn{7}{|c|}{$\begin{array}{ll} & 100.0 \\
\end{array}$} & 100.0 & 100.0 & 300.0 \\
\hline \multicolumn{10}{|c|}{$\begin{array}{l}\text { D }(\text { ind./ha })=\text { Density (Individual/hector), } \mathrm{F}(\%)=\text { Frequency (Percent); A= Abundance, } \mathrm{A} / \mathrm{F}=\mathrm{Abundance} / \mathrm{Frequency}, \\
\mathrm{RD}(\%)=\text { Relative Density (Percent) }, \mathrm{RF}(\%)=\text { Relative Frequency (Percent), RA }(\%)=\text { Relative Abundance (Percent) } \\
\text { IVI= Important Value Index. }\end{array}$} \\
\hline
\end{tabular}

\section{Quantitative analysis of Herbs:}

With respect to the herb species, a total of 93 species were enumerated during quadrate study. The highest density was measured in Aristida redacta (3.97 ind./sq.m.), followed by Aeluropus lagopoides (3.81 ind./sq.m.) and Halopyrum mucronatum (2.43 ind./sq.m). On the other hand, the lowest density (0.001 ind./sq. m.) was calculated in Vigna radiate,Striga gesneriodes, Ruellia tuberosa,Peristrophe bicalyculata, Leucas cephalotes, Indigofera linnaei, Glinus lotoides and Aristolochia bracteolata. However, the highest frequency was measured in Aristida redacta (39.02\%), followed by Aeluropus lagopoides (35.96\%) and Sporobolus maderaspatana (33.77\%). The lowest frequency $0.11 \%$ was measured in Vigna radiata, Striga gesneriodes, Ruellia tuberosa, Peristrophe bicalyculata, Leucas cephalotes, Indigofera linnaei, Glinus lotoides and Aristolochia bracteolata, Grangea maderaspatana and Tinospora cordifolia (Table 3).

The $\mathrm{A} / \mathrm{F}$ ratio of herb species in the coastal areas of Devbhoomi Dwarka district and its islands indicated contagious distribution pattern as ratio is higher than 0.05 (Table 3). A similar observation was found for herb species of a deforested area 
in Bangladesh which showed contagious distribution [40]. The present work reveals that, the study area was not completely uniform because several species showed contagious distribution [41] (Table 3). As a general rule, higher frequency and lower abundance indicates regular distribution pattern whereas the reverse indicates the contagious distribution. In general, regular distribution occurs where severe competition exists between individuals; random distribution is found in very uniform environment and contagious distribution is common in nature [41]. Contagious distribution depends on local habitat, seasonal weather changes and reproductive processes.

Based on IVI, Aristida redacta was the most dominant species followed by Aeluropus lagopoides, Halopyrum mucronatum, Sporobolus maderaspatana, Salicornia brachiata, Cyperus conglomeratus. On the other hand, the least dominant species were Vigna radiata ,Striga gesneriodes, Ruellia tuberosa, Peristrophe bicalyculata, Leucas cephalotes, Indigofera linnaei, Glinus lotoides and Aristolochia bracteolata (Table 3).

Table 3. Phytosociological attributes of herb species in coastal areas and its islands of Devbhoomi Dwarka district in GoK

\begin{tabular}{|c|c|c|c|c|c|c|c|c|c|}
\hline No. & Botanical name & $\mathrm{D}$ (ind./$/ \mathrm{m}^{2}$ ) & F (\%) & $\mathbf{A}$ & $\mathbf{A} / \mathbf{F}$ & RD (\%) & RF (\%) & RA (\%) & IVI \\
\hline 1 & Aristida redacta & 3.97 & 39.02 & 10.18 & 0.26 & 18.75 & 9.07 & 3.69 & 31.51 \\
\hline 2 & Aeluropus lagopoides & 3.81 & 35.96 & 10.60 & 0.29 & 18.00 & 8.36 & 3.85 & 30.21 \\
\hline 3 & Halopyrum mucronatum & 2.43 & 14.43 & 16.83 & 1.17 & 11.47 & 3.35 & 6.11 & 20.93 \\
\hline 4 & Sporobolus maderaspatana & 1.94 & 33.77 & 5.75 & 0.17 & 9.17 & 7.85 & 2.09 & 19.11 \\
\hline 5 & Cyperus conglomeratus & 1.04 & 17.60 & 5.94 & 0.34 & 4.93 & 4.09 & 2.16 & 11.18 \\
\hline 6 & Salicornia brachiata & 1.00 & 5.79 & 17.26 & 2.98 & 4.72 & 1.35 & 6.27 & 12.34 \\
\hline 7 & Indigofera cordifolia & 0.76 & 20.87 & 3.65 & 0.17 & 3.60 & 4.85 & 1.32 & 9.77 \\
\hline 8 & Pulicaria wightiana & 0.71 & 16.72 & 4.27 & 0.26 & 3.37 & 3.89 & 1.55 & 8.81 \\
\hline 9 & Goniogyna hirta & 0.44 & 15.30 & 2.89 & 0.19 & 2.09 & 3.56 & 1.05 & 6.70 \\
\hline 10 & Cressa cretica & 0.42 & 11.37 & 3.73 & 0.33 & 2.00 & 2.64 & 1.35 & 6.00 \\
\hline 11 & Lepidagathis trinervis & 0.39 & 16.28 & 2.41 & 0.15 & 1.85 & 3.79 & 0.87 & 6.51 \\
\hline 12 & Boerhavia chinensis & 0.39 & 18.36 & 2.10 & 0.11 & 1.82 & 4.27 & 0.76 & 6.85 \\
\hline 13 & Barleria prionitis & 0.35 & 16.07 & 2.16 & 0.13 & 1.64 & 3.73 & 0.79 & 6.16 \\
\hline 14 & Aerva lanata & 0.31 & 13.33 & 2.34 & 0.18 & 1.48 & 3.10 & 0.85 & 5.43 \\
\hline 15 & Cyperus pangorei & 0.31 & 10.27 & 2.99 & 0.29 & 1.45 & 2.39 & 1.09 & 4.92 \\
\hline 16 & Abutilon glaucum & 0.29 & 12.46 & 2.32 & 0.19 & 1.36 & 2.90 & 0.84 & 5.10 \\
\hline 17 & Fimbristylis cymosa & 0.28 & 9.29 & 3.01 & 0.32 & 1.32 & 2.16 & 1.09 & 4.57 \\
\hline 18 & Achyranthes aspera & 0.24 & 10.16 & 2.41 & 0.24 & 1.16 & 2.36 & 0.87 & 4.39 \\
\hline 19 & Aloe barbadensis & 0.15 & 7.21 & 2.03 & 0.28 & 0.69 & 1.68 & 0.74 & 3.11 \\
\hline 20 & Juncus maritimus & 0.12 & 5.14 & 2.26 & 0.44 & 0.55 & 1.19 & 0.82 & 2.56 \\
\hline 21 & Apluda mutica & 0.11 & 0.55 & 20.40 & 37.33 & 0.53 & 0.13 & 7.41 & 8.06 \\
\hline 22 & Boerhavia diffusa & 0.10 & 6.12 & 1.68 & 0.27 & 0.49 & 1.42 & 0.61 & 2.52 \\
\hline 23 & Celosia argentea & 0.10 & 5.57 & 1.84 & 0.33 & 0.49 & 1.30 & 0.67 & 2.45 \\
\hline 24 & Alysicarpus longifolius & 0.09 & 0.66 & 13.50 & 20.59 & 0.42 & 0.15 & 4.90 & 5.47 \\
\hline 25 & Clitoria ternatea & 0.09 & 5.90 & 1.50 & 0.25 & 0.42 & 1.37 & 0.54 & 2.33 \\
\hline 26 & Asparagus recemosus & 0.09 & 7.65 & 1.14 & 0.15 & 0.41 & 1.78 & 0.41 & 2.61 \\
\hline 27 & Echinops echinatus & 0.07 & 3.83 & 1.94 & 0.51 & 0.35 & 0.89 & 0.71 & 1.95 \\
\hline 28 & Suaeda fruticosa & 0.07 & 0.66 & 10.33 & 15.76 & 0.32 & 0.15 & 3.75 & 4.22 \\
\hline 29 & Launaea procumbens & 0.07 & 4.48 & 1.49 & 0.33 & 0.31 & 1.04 & 0.54 & 1.90 \\
\hline 30 & Sida cordifolia & 0.07 & 5.14 & 1.30 & 0.25 & 0.31 & 1.19 & 0.47 & 1.98 \\
\hline 31 & Fagonia cretica & 0.06 & 4.04 & 1.38 & 0.34 & 0.26 & 0.94 & 0.50 & 1.70 \\
\hline 32 & Argemone maxicana & 0.05 & 3.72 & 1.44 & 0.39 & 0.25 & 0.86 & 0.52 & 1.64 \\
\hline 33 & Heliotropium curassivicum & 0.05 & 3.06 & 1.68 & 0.55 & 0.24 & 0.71 & 0.61 & 1.56 \\
\hline 34 & Cleome viscosa & 0.05 & 3.93 & 1.25 & 0.32 & 0.23 & 0.91 & 0.45 & 1.60 \\
\hline 35 & Commelina benghalensis & 0.05 & 1.86 & 2.53 & 1.36 & 0.22 & 0.43 & 0.92 & 1.57 \\
\hline 36 & Enicostema hyssopifolium & 0.04 & 2.51 & 1.78 & 0.71 & 0.21 & 0.58 & 0.65 & 1.44 \\
\hline 37 & Acanthospermum hispidum & 0.04 & 0.87 & 4.63 & 5.29 & 0.19 & 0.20 & 1.68 & 2.07 \\
\hline 38 & Coculus hirsutus & 0.04 & 2.51 & 1.43 & 0.57 & 0.17 & 0.58 & 0.52 & 1.28 \\
\hline 39 & Polycarpaea corymbosa & 0.04 & 0.22 & 16.50 & 75.49 & 0.17 & 0.05 & 5.99 & 6.21 \\
\hline
\end{tabular}




\begin{tabular}{|c|c|c|c|c|c|c|c|c|c|}
\hline $\begin{array}{l}\text { No. } \\
40\end{array}$ & $\begin{array}{l}\text { Botanical name } \\
\text { Solanum indicum }\end{array}$ & $\begin{array}{l}\text { D (ind./ } \mathbf{m}^{2} \text { ) } \\
0.03\end{array}$ & $\begin{array}{l}\mathbf{F}(\boldsymbol{\%}) \\
2.62\end{array}$ & $\begin{array}{r}\mathbf{A} \\
1.33 \\
\end{array}$ & $\begin{array}{c}\mathbf{A} / \mathbf{F} \\
0.51\end{array}$ & $\begin{array}{l}\text { RD (\%) } \\
0.17\end{array}$ & $\begin{array}{l}\mathbf{R F}(\boldsymbol{\%}) \\
0.61\end{array}$ & $\begin{array}{l}\text { RA (\%) } \\
0.48\end{array}$ & $\begin{array}{l}\text { IVI } \\
1.26\end{array}$ \\
\hline 41 & Tridax procumbens & 0.03 & 0.77 & 4.57 & 5.98 & 0.17 & 0.18 & 1.66 & 2.00 \\
\hline 42 & Cucumis propheratum & 0.03 & 3.06 & 1.04 & 0.34 & 0.15 & 0.71 & 0.38 & 1.24 \\
\hline 43 & Coldenia procumbens & 0.03 & 2.30 & 1.33 & 0.58 & 0.14 & 0.53 & 0.48 & 1.16 \\
\hline 44 & Convolvulus microphyllus & 0.03 & 1.97 & 1.44 & 0.73 & 0.13 & 0.46 & 0.52 & 1.12 \\
\hline 45 & Coccinia grandis & 0.03 & 1.64 & 1.53 & 0.94 & 0.12 & 0.38 & 0.56 & 1.06 \\
\hline 46 & Solanum surattense & 0.02 & 1.97 & 1.22 & 0.62 & 0.11 & 0.46 & 0.44 & 1.01 \\
\hline 47 & Justisia procumbens & 0.02 & 0.66 & 3.50 & 5.34 & 0.11 & 0.15 & 1.27 & 1.53 \\
\hline 48 & Heliotropium ovalifolium & 0.02 & 1.42 & 1.54 & 1.08 & 0.10 & 0.33 & 0.56 & 0.99 \\
\hline 49 & Limonium stocksii & 0.02 & 1.09 & 1.60 & 1.46 & 0.08 & 0.25 & 0.58 & 0.92 \\
\hline 50 & Pentatropis spiralis & 0.02 & 1.31 & 1.33 & 1.02 & 0.08 & 0.30 & 0.48 & 0.87 \\
\hline 51 & Dactyloctenium aegyptium & 0.02 & 0.22 & 7.50 & 34.31 & 0.08 & 0.05 & 2.72 & 2.85 \\
\hline 52 & Euphorbia hirta & 0.02 & 1.20 & 1.27 & 1.06 & 0.07 & 0.28 & 0.46 & 0.81 \\
\hline 53 & Sericostoma pauciflorum & 0.02 & 0.98 & 1.56 & 1.58 & 0.07 & 0.23 & 0.56 & 0.87 \\
\hline 54 & Citrullus colocynthis & 0.01 & 0.77 & 1.71 & 2.24 & 0.06 & 0.18 & 0.62 & 0.86 \\
\hline 55 & Ipomoea obscura & 0.01 & 0.87 & 1.50 & 1.72 & 0.06 & 0.20 & 0.54 & 0.81 \\
\hline 56 & Rhynchosia minima & 0.01 & 0.87 & 1.50 & 1.72 & 0.06 & 0.20 & 0.54 & 0.81 \\
\hline 57 & Iротоеа eriocarpa & 0.01 & 1.09 & 1.10 & 1.01 & 0.06 & 0.25 & 0.40 & 0.71 \\
\hline 58 & Cucumis callosus & 0.01 & 1.09 & 1.00 & 0.92 & 0.05 & 0.25 & 0.36 & 0.67 \\
\hline 59 & Sesuvium portulacastrum & 0.01 & 0.87 & 1.13 & 1.29 & 0.05 & 0.20 & 0.41 & 0.66 \\
\hline 60 & Cistanche tubulosa & 0.01 & 0.66 & 1.33 & 2.03 & 0.04 & 0.15 & 0.48 & 0.68 \\
\hline 61 & Vernonia cinerea & 0.01 & 0.77 & 1.14 & 1.49 & 0.04 & 0.18 & 0.41 & 0.63 \\
\hline 62 & $\begin{array}{l}\text { Cardiospermum } \\
\text { halicacabum }\end{array}$ & 0.01 & 0.44 & 1.75 & 4.00 & 0.04 & 0.10 & 0.64 & 0.77 \\
\hline 63 & Ipomoea pes-carpae & 0.01 & 0.55 & 1.40 & 2.56 & 0.04 & 0.13 & 0.51 & 0.67 \\
\hline 64 & Pedalium murex & 0.01 & 0.55 & 1.20 & 2.20 & 0.03 & 0.13 & 0.44 & 0.59 \\
\hline 65 & Physalis minima & 0.01 & 0.33 & 2.00 & 6.10 & 0.03 & 0.08 & 0.73 & 0.83 \\
\hline 66 & Abutilon indicum & 0.01 & 0.55 & 1.00 & 1.83 & 0.03 & 0.13 & 0.36 & 0.52 \\
\hline 67 & Cassia pumila & 0.01 & 0.33 & 1.67 & 5.08 & 0.03 & 0.08 & 0.61 & 0.71 \\
\hline 68 & Commelina forskalaei & 0.01 & 0.33 & 1.67 & 5.08 & 0.03 & 0.08 & 0.61 & 0.71 \\
\hline 69 & Corchorus depressus & 0.01 & 0.55 & 1.00 & 1.83 & 0.03 & 0.13 & 0.36 & 0.52 \\
\hline 70 & Dactyloctenium sindicum & 0.01 & 0.55 & 1.00 & 1.83 & 0.03 & 0.13 & 0.36 & 0.52 \\
\hline 71 & Eclipta prostrata & 0.01 & 0.22 & 2.50 & 11.44 & 0.03 & 0.05 & 0.91 & 0.98 \\
\hline 72 & Rungia repens & 0.01 & 0.55 & 1.00 & 1.83 & 0.03 & 0.13 & 0.36 & 0.52 \\
\hline 73 & Desmostachya bipinnata & 0.004 & 0.33 & 1.33 & 4.07 & 0.02 & 0.08 & 0.48 & 0.58 \\
\hline 74 & Leucas aspera & 0.004 & 0.33 & 1.33 & 4.07 & 0.02 & 0.08 & 0.48 & 0.58 \\
\hline 75 & Polygala erioptera & 0.004 & 0.44 & 1.00 & 2.29 & 0.02 & 0.10 & 0.36 & 0.49 \\
\hline 76 & Alysicarpus procumbens & 0.003 & 0.22 & 1.50 & 6.86 & 0.02 & 0.05 & 0.54 & 0.61 \\
\hline 77 & Ipomoea coptica & 0.003 & 0.33 & 1.00 & 3.05 & 0.02 & 0.08 & 0.36 & 0.45 \\
\hline 78 & Ocimum basilicum & 0.003 & 0.33 & 1.00 & 3.05 & 0.02 & 0.08 & 0.36 & 0.45 \\
\hline 79 & Pergularia daemia & 0.003 & 0.33 & 1.00 & 3.05 & 0.02 & 0.08 & 0.36 & 0.45 \\
\hline 80 & Polycarpaea spicata & 0.003 & 0.33 & 1.00 & 3.05 & 0.02 & 0.08 & 0.36 & 0.45 \\
\hline 81 & Tinospora cordifolia & 0.003 & 0.11 & 3.00 & 27.45 & 0.02 & 0.03 & 1.09 & 1.13 \\
\hline 82 & Aerva ljavanica & 0.002 & 0.22 & 1.00 & 4.58 & 0.01 & 0.05 & 0.36 & 0.42 \\
\hline 83 & Amberboa ramosa & 0.002 & 0.22 & 1.00 & 4.58 & 0.01 & 0.05 & 0.36 & 0.42 \\
\hline 84 & Chrozophora rottleri & 0.002 & 0.22 & 1.00 & 4.58 & 0.01 & 0.05 & 0.36 & 0.42 \\
\hline 85 & Grangea maderaspatana & 0.002 & 0.11 & 2.00 & 18.30 & 0.01 & 0.03 & 0.73 & 0.76 \\
\hline 86 & Aristolochia bracteolata & 0.001 & 0.11 & 1.00 & 9.15 & 0.01 & 0.03 & 0.36 & 0.39 \\
\hline 87 & Glinus lotoides & 0.001 & 0.11 & 1.00 & 9.15 & 0.01 & 0.03 & 0.36 & 0.39 \\
\hline 88 & Indigofera linnaei & 0.001 & 0.11 & 1.00 & 9.15 & 0.01 & 0.03 & 0.36 & 0.39 \\
\hline 89 & Leucas cephalotes & 0.001 & 0.11 & 1.00 & 9.15 & 0.01 & 0.03 & 0.36 & 0.39 \\
\hline 90 & Peristrophe bicalyculata & 0.001 & 0.11 & 1.00 & 9.15 & 0.01 & 0.03 & 0.36 & 0.39 \\
\hline
\end{tabular}




\begin{tabular}{|c|c|c|c|c|c|c|c|c|c|}
\hline No. & Botanical name & D (ind. $\left./ \mathrm{m}^{2}\right)$ & F (\%) & $\mathbf{A}$ & $\mathbf{A} / \mathbf{F}$ & $\mathbf{R D}(\%)$ & RF (\%) & RA $(\%)$ & IVI \\
\hline 91 & Ruellia tuberosa & 0.001 & 0.11 & 1.00 & 9.15 & 0.01 & 0.03 & 0.36 & 0.39 \\
\hline 92 & Striga gesneriodes & 0.001 & 0.11 & 1.00 & 9.15 & 0.01 & 0.03 & 0.36 & 0.39 \\
\hline 93 & Vigna radiata & 0.001 & 0.11 & 1.00 & 9.15 & 0.01 & 0.03 & 0.36 & 0.39 \\
\hline
\end{tabular}

D $\left(\right.$ ind.$\left./ \mathrm{m}^{2}\right)=$ Density (Individual/Square meter), F $(\%)=$ Frequency (Percent); A= Abundance, A/F= Abundance/Frequency, $\mathrm{RD}(\%)=$ Relative Density (Percent), $\mathrm{RF}(\%)=$ Relative Frequency (Percent), RA $(\%)=$ Relative Abundance (Percent),

IVI= Important Value Index.

\section{Plant Species Diversity:}

Measurement of biodiversity concentrates on the species level and species diversity is one of the most important indices which are used for the evaluation of ecosystems at different scales [42]. The Shannon-Wiener Index (H') and Simpson's index (c) were used to determine which community is more diverse. A large value of H'Index indicates rich ecosystem with high species diversity, whereas a low value of H'Index represents an ecosystem with little diversity [43]. An ecosystem with $H^{\prime}$ value greater than 2 has been regarded as medium to high diverse in terms of species [44]. The probability that two individuals chosen at random will be the same species is measured by The Simpson's Index. Because of this, the range for the Simpson's Index (c) is from Zero to One. Zero is the least diverse and one is the highest level of diversity attainable with this index [43]. In the present study Shannon-Wiener diversity (H') index and Simpson's index (c) was 3.113 and 0.916 , respectively. Thus the coastal area of Devbhoomi Dwarka District and its islands has rationally high species diversity.

The study came with index of dominance of 1.190 for the coastal area of Devbhoomi Dwarka District and its islands. The greater value of index of dominance exhibits the lower species diversity and vice versa in the scale of 0 to 1 [45].

Species richness and evenness are the two separate ideas of heterogeneity- it is only natural to try to measure the evenness component separately. In 1964, Lloyd and Ghelardi [46] were the first who came with idea to measure the evenness component of diversity separately [47]. Evenness describes how equally individuals are distributed amongst the species. Pielou's evenness index (e) was 0.794 and Margalef species richness index (d) was 10.87 in the study area.

\section{CONCLUSION}

Floristic diversity assessment at local and regional levels is required to understand the present status and to make effective management strategies for conservation. The results in the present study clearly show that, the Coastal areas of Devbhoomi Dwarka district and its islands are rich in phytodiversity. A record of 243 species during the study period reflects that the coastal areas of Devbhoomi Dwarka district and its islands have the potential to harbour rich species diversity with various ecological services. The present finding provides an assessment on floral diversity, density, frequency and important value index which will be helpful for preparing a sustainable management plan. Moreover the study results will serve as a primary input towards monitoring and sustaining the phytodiversity of the coastal areas of Devbhoomi Dwarka district and its islands in the Gulf of Kachchh.

\section{ACKNOWLEDGEMENTS}

The authors are highly grateful to the World Bank, Ministry of Environment and Forest \& Climate Change (MoEF \& CC), National Project Management Unit- Society of Integrated Coastal Management (NPMU-SICOM), and State Project Management Unit- Gujarat Ecology Commission (SPMU-GEC) for providing the financial assistance for this work under the Integrated Coastal Zone Management Project. Thanks are also due to Gujarat Forests Department and Marine National Park \& Sanctuary (MNP\&S) for providing the permission to carry out this research. Authors would also like to thank Gujarat Ecological Education and research (GEER) Foundation and its staff for giving the platform to carry out the research work, collection of field data and laboratory analysis.

\section{REFERENCES}

[1]. R.H. Wagner, "The Ecology of dunes - strand habitat of North Carolina.Ecological Monogarphs", Vol. 34, pp. 79-96, 1964.

[2]. J. Dahm, G. Jenks and D. Bergin, "Community-based dune management for the mitigation of coastal hazards and climate change effects: A guide for local authorities." Electronic database available at www.envbop.govt.nz/Reports/ClimateChange-0505- coastal hazards and climate Report, Pdf, Technical report, New Zealand, 2005.

[3]. W. Burns, “A Study of the sea shore vegetation”, J. Bombey Nat. Hist. Soc. Vol. 20, pp. 47-49, 1910.

[4]. T. A. Rao, and B. Safui, "Some rare plants along Saurashtra coast and neighbouring islands", Proc. Indian Acad. Sci. Vol. 58, Issue B, pp. 362-366, 1963. 
[5]. V.J. Chapman, “Coastal Vegetation”, Pergamon Press, London, pp.1-245, 1964.

[6]. T.A. Rao, K.R. Aggrawal, "An Ecological studies of Saurastra coast and neighbouring islands. III. -Okhamandal point to Diu coastal areas", UNESCO, Proc. Symp. Prob. Indian Arid Zone, Jodhpur. pp. 31-42, 1964.

[7]. T.A., Rao, K.R. Aggrawal, “An Ecological studies of Saurastra coast and neighbouring islands. II. Beyt island”, Bull. Bot. Surv. India. Vol. 8, pp. 16-24. 1966.

[8]. T.A., Rao, K.R. Aggrawal, and A. K. Mukherjee, “An Ecological studies of Saurastra coast and neighbouring islands. IV. Piram Island”, Bull. Bot. Surv. India, Vol. 8, pp. 60-67, 1966.

[9]. S. K. Jain, "The vegetation and succession of plant communities in Kutch, Gujarat", Proceedings of the Symposium on Recent Advances in Tropical Ecology, pp.426-437, 1968.

[10]. R.K. Arora, and K. R. Aggrawal, “Observation on the vegetation of Malpe coast and neighbouring Islands”, J. Indian Bot. Soc., Vol. 44, Issue 3, pp. 314-325, 1965.

[11]. T.A. Rao, "Distributional resume on the maritime strand flora of India”, Bull. Bot. Surv. India. Vol. 13, Issue 3-4, pp.192-202, 1971.

[12]. N.P. Balakrishanan, “Andaman Islands- Vegetation \& Florastics” In Saldanha, C.J. (ed.). Oxford \& IBH Publishing Co. Pvt. Ltd., New Delhi, 1989.

[13]. L. K. Banerjee, "Conservation of coastal plant communities in India”, Bull. Bot. Surv. India Vol. 36(1-4), pp.160-165, 1994.

[14]. L.K. Banerjee, "Coastal Wetland Plant Communities of India", Manual of marine - Coastal pollution and its Abatement. Central Pollution Control Board, E.Zone, Calcutta, pp.120-127, 2000.

[15]. L.K. Banerjee, "Diversity of Coastal Plant Communities in India”, ENVIS-EMCB, Botanical Survey of India, Ministry and Forests, Kolkata, 2002.

[16]. B.P. Khokhariya, M. S. Mali, and Y. B. Dabgar, “Diversity Of Habitat And Biological Spectrum Of Bet Dwarka Island, Gujarat, India” Life Sciences Leaflets, Vol. 50, pp.11-18, 2014.

[17]. Gujarat Ecological Commission, "Ecological Profile for Coastal talukas of GOK Overview Report”, Gandhinagar, Gujarat, 2014.

[18]. http://dcmsme.gov.in/dips/2016 17/Dev\%20Bhumi\%20Dwarka-\%202016-17.pdf

[19]. http://www.icmam.gov.in/ GOK.PDF

[20]. http://www. gsdma.org/rainfall. Aspx

[21]. K. A. Kershaw, “Quantitative and Dynamic plant ecology”, 2nd Edn, Edward Arnold, London, pp.308, 1973.

[22]. R. Mishra, "Ecology Work Book", Oxford and IBH publishing Co., Calcutta, 1968.

[23]. C. D. Bonham, “Measurements for terrestrial Vegetation”, John Wiley \& Sons, New York, N.Y. pp. 338. (1989).

[24]. T. Cooke, "The Flora of the Presidency of Bombay", Taylon \& Francis, London. (1901-1908).

[25]. H. Santapau, "The flora of Saurashtra, Part I. Rannunculaceae to Rubiaceae", Saurashtra Research Society, Rajkot, Vol-1, 1962.

[26]. H. Santapau, and K. P. Janardhanan, "Provided the flora of Saurashtra; check list”, Bull. Bot. Surv. India Vol. 8 (supplement 1), pp. 1-58, 1966.

[27]. P. V. Bole, and J. M. Pathak, "Flora of Saurashtra”, Part 2 \& 3, Director, Botanical Survey of India, Kolkata, 1988.

[28]. G. L. Shah, "Flora of Gujarat State”, Vol. I \& II. Sardar Patel University Press, Vallabh Vidyanagar, 1978.

[29]. R.S., Shukla and P.S Chandel, "Plant Ecology and Soil Science”, 9th.Ed. S. Chand \& Company Limited, Ramnagor, New Delhi, 2000.

[30]. P.B. Whitford, "Distribution of woodland plants in relation to succession and clonal growth", Ecology, Vol. 30, pp.199-208, 1948.

[31]. P. Michael, "Ecological methods for field and laboratory investigation", Tata Mc Graw Hill Publishing Co. Ltd., New Delhi, pp. $404,1990$.

[32]. E. H. Simpson, "Measurement of diversity", Nature, Vol. 163, pp. 688, 1949.

[33]. E. C. Pielou, "The measurement of diversity in different types of biological collections" J. Theoret. Biol., Vol. 13, pp. 131-144, 1966.

[34]. R. Margalef, "Temporal succession and spatial heterogeneity in phytoplankton”, In: Perspectives in Marine biology, Buzzati-Traverso (ed.), Univ. Calif. Press, Berkeley, pp. 323-347, 1958.

[35]. S.B. Frackler, and H.A. Brischle, "Measuring the local distribution of Ribes", Ecology, Vol. 25, pp. 283-303, 1944.

[36]. L.M.C. Cole, “A theory for analysing contagiously distributed population, Ecology”, Vol. 2, pp.329-341, 1946.

[37]. E. Ashby, "Statistical Ecology: A re-assessment”, Bot. Rev., Vol. 14, pp. 222-224, 1948.

[38]. J. T. Curtis and G. Cottam, "Plant Ecology Work Book - Laboratory Field Reference Manual", Burgress Publication Company, Minneapolis, Minnesota, pp. 193. 1956.

[39]. J. T., Curtis. And R. P. McIntosh, "An Upland continuum in the Praine Forest Border region of Wisconsin, Ecology", Vol.32, pp. 476-496, 1951.

[40]. M.Al-Amin, M. Alamgir, and M. R. A. Patwary, "Composition and Status of Undergrowth of a Deforested Area in Bangladesh”, Asian Journal of Plant Sciences, Vol. 3, pp. 651-654, 2004.

[41]. E. P. Odum, “Fundametals of ecology”, Saunders Compny Philadelphia, USA, 1971.

[42]. M. R. Ardakani, "Ecology”, Tehran University Press, pp. 340, 2004.

[43]. S Robertson, "Biodiversity in a Florida Sandhill Ecosystem", Undergraduate Journal of Mathematical Modeling: One + Two, Vol. 2, Issue 1, pp. 6, 2009.

[44]. M. Barbour, J. H. Burk, W. D. Pitts, F. S. Gillians, M. W. Schwartz, “Terrestrial Ecology”, Chicago, Illinois: Addson Wesley Longman, Inc, pp. 69-85, 1999.

[45]. K. C. Misra, "Manual of Plant Ecology”, 3rd Edition, Oxford and IBH Publishing Co. Pvt. Ltd. New Delhi , 1989.

[46]. M. Lloyd, and R. J. Ghelardi, "A table for calculating the "equitability" component of species diversity", Journal of Animal Ecology, Vol. 33, pp. 217-225, 1964.

[47]. C. J. Krebs, “Ecologocal methodology” Harper \& Row, New York, pp. 1-471, 1989.

\section{AUTHORS PROFILE}

Dr. Lopamudra Das is Research Associate working on Coastal and Marine Flora in Gujarat Ecological Education and Research (GEER) Foundation, Gandhinagar. She has completed her Doctor of Philosophy in the field of Botany from the RTM Nagpur University, Maharashtra. She has been actively involved in ecological study of Coastal Plants, Seaweeds and Mangroves diversity for last 8 years. Dr. 
Lopamudra Das has published ten research papers in International and National Journals and also contributed in publication of many technical reports and books published by GEER Foundation. She has also been contributing in various ecological awareness activities at GEER Foundation.

Dr. Harshad Salvi, has done his Ph.D. from HNGU, Patan, was actively involved in a number of biodiversity of Protected Areas (Pas) at Gujarat State related to plant diversity as well as pollination biology \& reproductive ecology of rare mangrove species studies as scientist in GEER Foundation. He has over 18 years of research experience in coastal, corals, grassland and forest ecosystems of Gujarat State and has published 12 research Papers. Presently he is serving as Assistant professor and Head, Botany Department, Government Science College, Songadh, Tapi, Gujarat.

Mr. R. D. Kamboj is an Indian Forest Services Officer of Gujarat cadre (1986 batch) of the rank of Additional Principal Chief Conservator of Forests. He holds post graduate degree in Agriculture from Haryana Agriculture University, Hisar \& in Forestry from Indira Gandhi National Forest Academy, Dehradun. He has served in various positions in Gujarat Forest Department for last 32 years. He has published more than 70 research papers and has written Working Plans/ Management Plans for various forest divisions including Gir National Park \& Sanctuary. Presently he is serving as Director, Gujarat Ecological Education and Research (GEER) Foundation, Gandhinagar. 
Annexure 1. Checklist of Coastal Terrestrial Plants of Devbhoomi Dwarka District and its islands

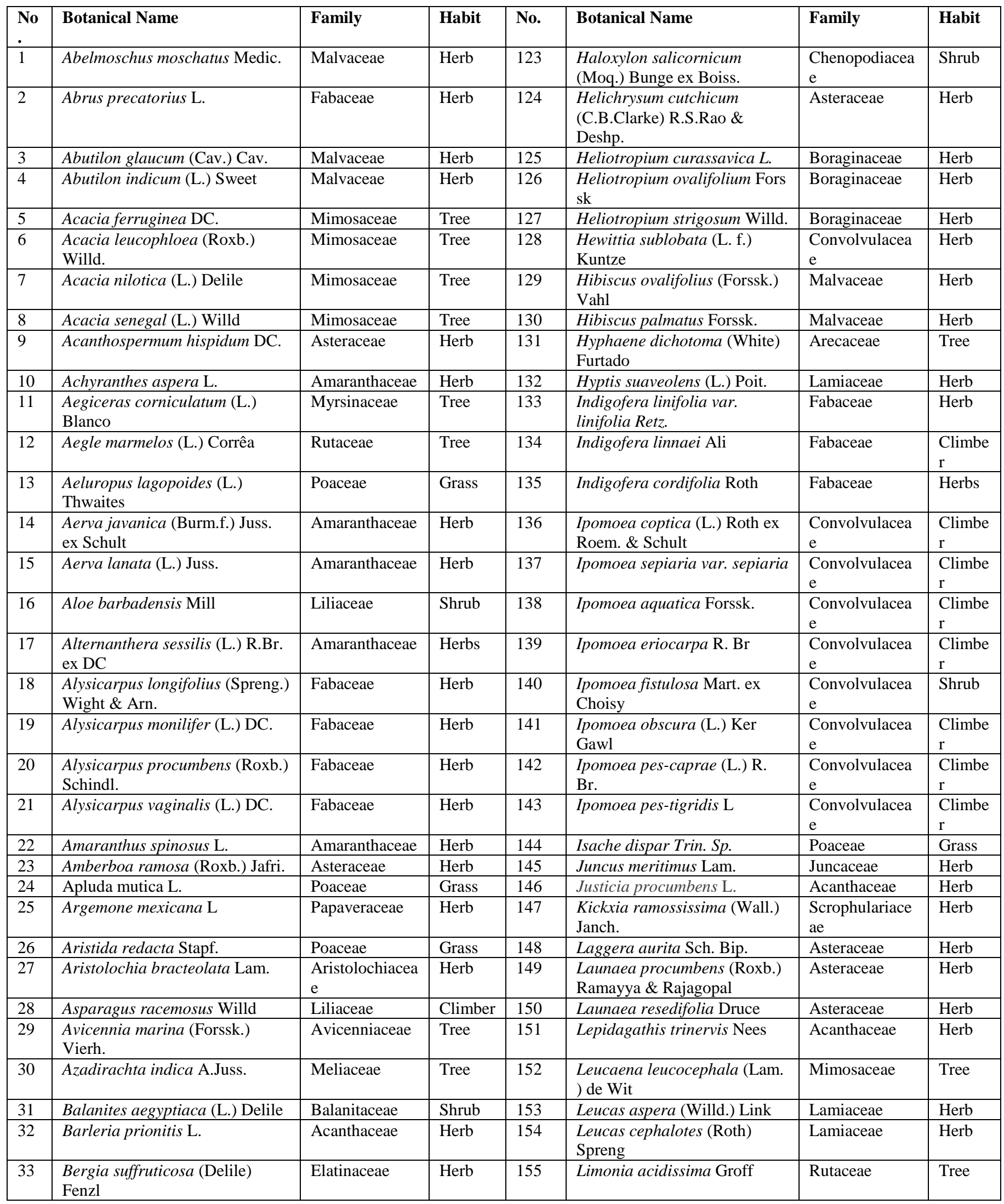




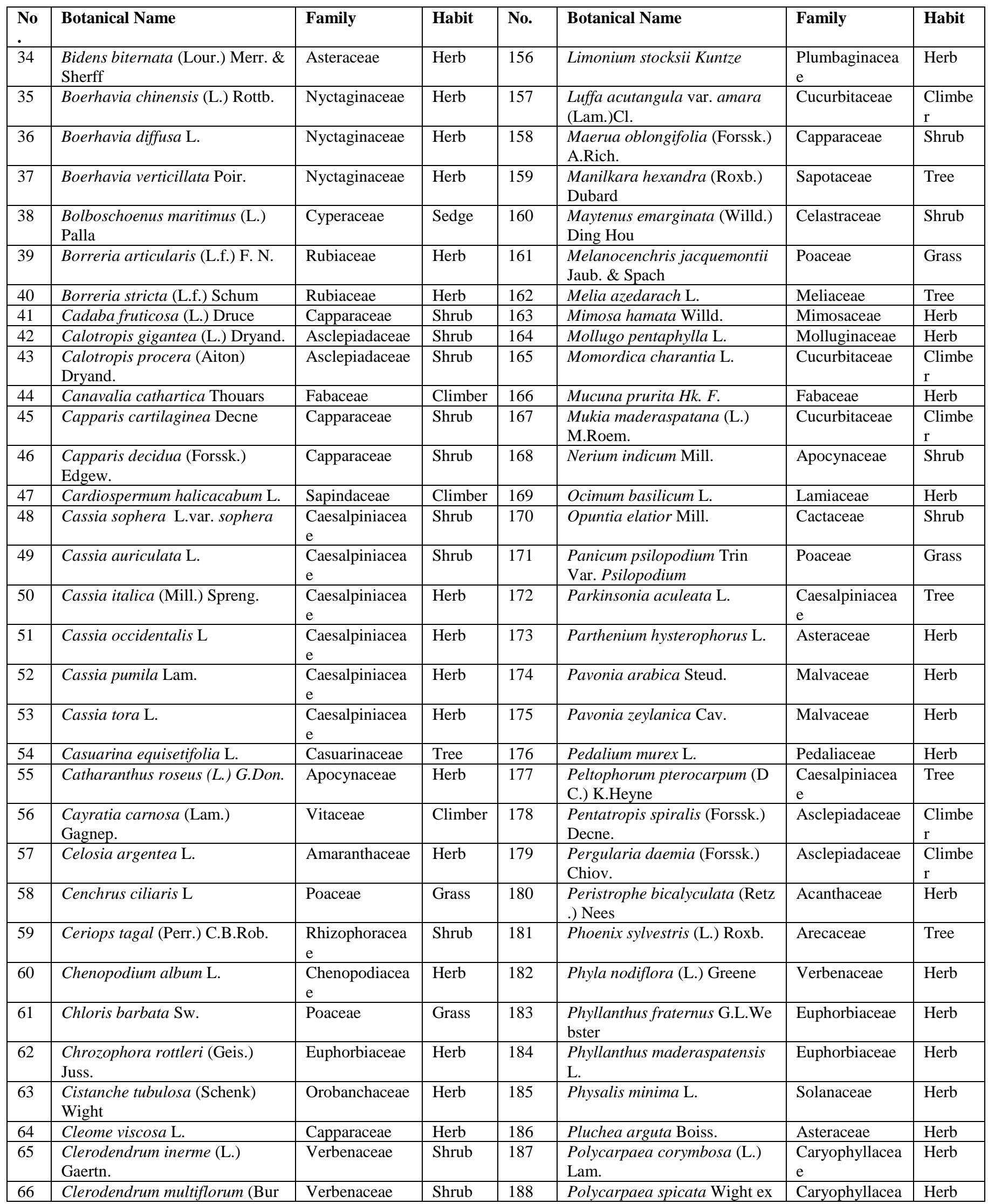




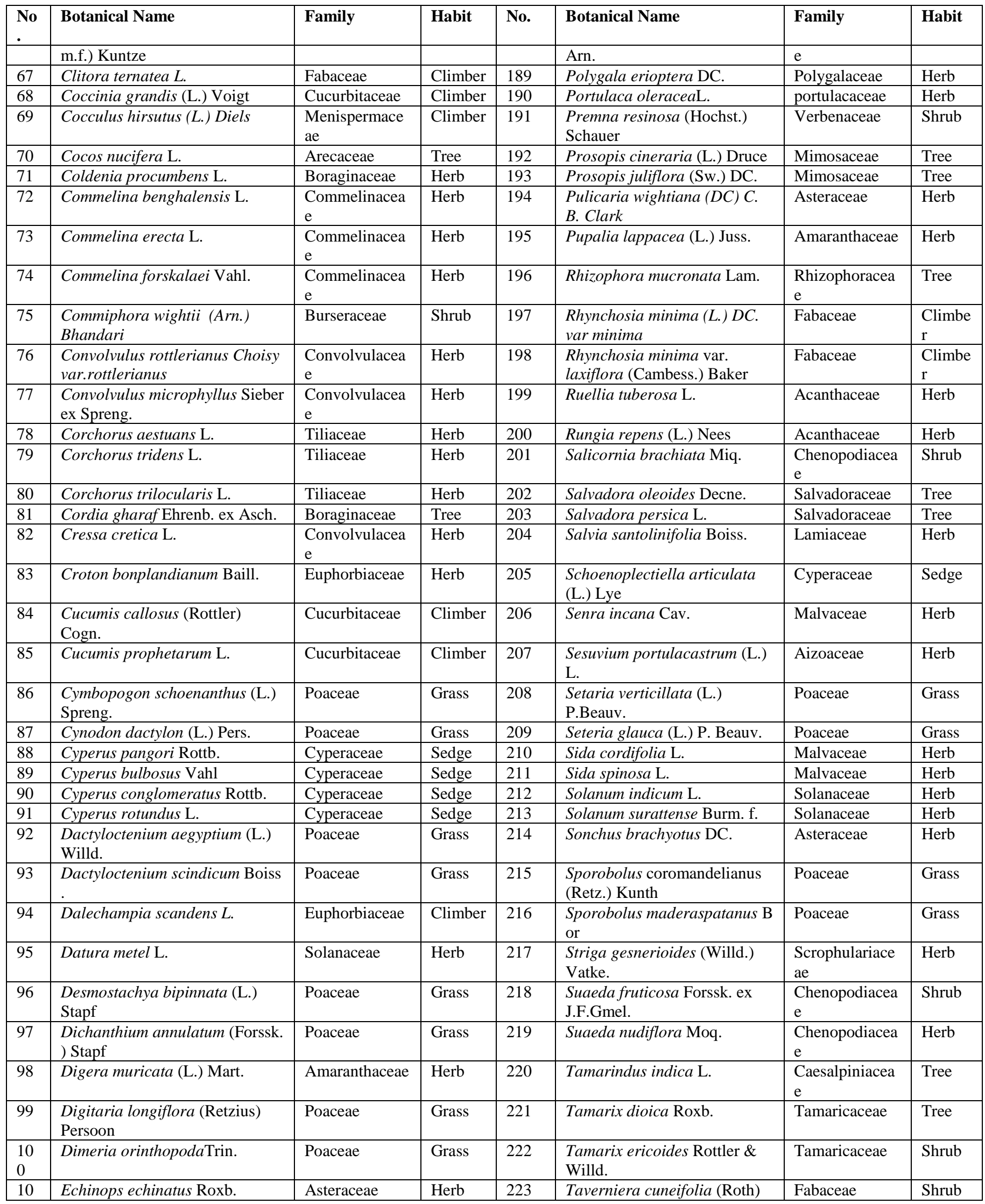




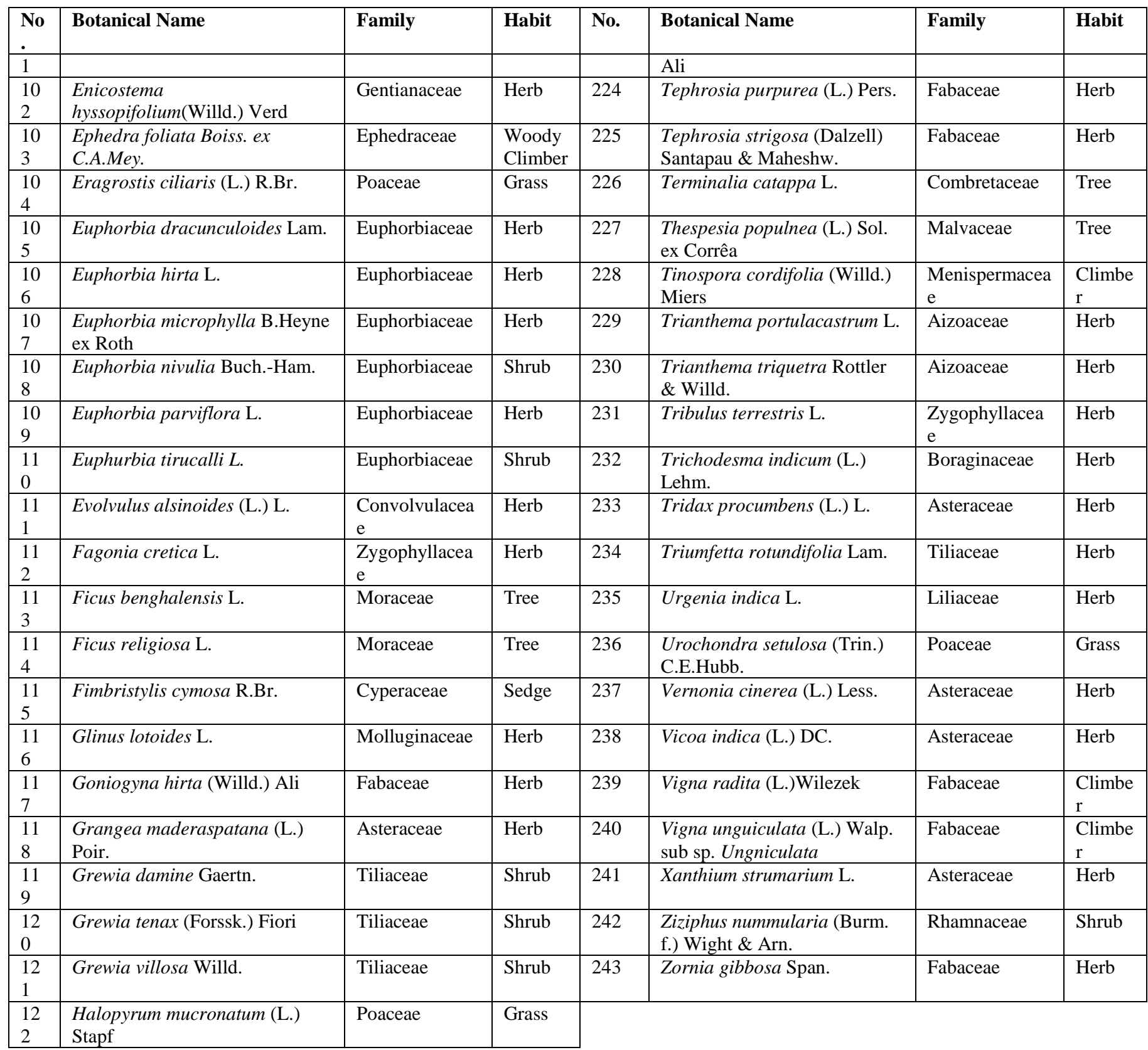

